\title{
Polychlorinated biphenyls (PCBs) alter DNA methylation and genomic integrity of sheep fetal cells in a simplified in vitro model of pregnancy exposure ${ }^{\text {is }}$
}

\author{
Debora A. Anzalone ${ }^{\mathrm{a}}$, Silvestre Sampino ${ }^{\mathrm{a}, \mathrm{b}}$, Marta Czernik ${ }^{\mathrm{a}}$, Domenico Iuso ${ }^{\mathrm{a}}$, Grazyna E. Ptak ${ }^{\mathrm{a}, \mathrm{b}, \mathrm{c}, *}$ \\ a Department of Biomedical Sciences, University of Teramo, Italy \\ ${ }^{\mathrm{b}}$ Institute of Genetics and Animal Breeding, Polish Academy of Sciences, Poland \\ ${ }^{\mathrm{c}}$ Malopolska Centre of Biotechnology, Jagiellonian University, Cracow, Poland
}

\section{A R T I C L E I N F O}

\section{Keywords:}

PCBs

Sheep pregnancy

Fetal fibroblast

Amniocytes

DNA methylation

Chromosomal aberrations

\begin{abstract}
A B S T R A C T
Polychlorinated biphenyls (PCBs) are persistent organic pollutants ubiquitously detectable in the environment and in the food chain. Prenatal exposure to PCBs negatively affects fetal development and produces long-term detrimental effects on child health. The present study sought to evaluate the cytotoxic and genotoxic effects of chronic PCB exposure on fetal cells during pregnancy. To this aim, sheep embryonic fibroblasts (SEF) and amniocytes (SA) were cultured in vitro in the presence of low doses of PCBs for a period of 120 days, comparable to the full term of ovine pregnancy. Cellular proliferation rates, global DNA methylation, chromosome integrity, and markers of DNA damage were evaluated at different time points. Moreover, SEF treated with PCBs for 60 days were left untreated for one further month and then examined in order to evaluate the reversibility of PCB-induced epigenetic defects. PCB-treated SEF were more sensitive than SA treated with PCBs, in terms of low cell proliferation, and increased DNA damage and global DNA methylation, which were still detectable after interruption of PCB treatment. These data indicate that chronic exposure of fetal cells to PCBs causes permanent genomic and epigenetic instability, which may influence both prenatal and post-natal growth up to adulthood. Our in vitro model offer a simple and controlled means of studying the effects of different contaminants on fetal cells - one that could set the stage for targeted in vivo studies.
\end{abstract}

\section{Introduction}

Polychlorinated biphenyls (PCBs) are organic chlorine compounds that were largely used as lubricating oils in transformers and capacitors, and as hydraulic fluids, plasticizers, and pesticides (Safe, 1992) until were found highly toxic and banned in the 1970s. Despite the ban, PCBs are still persistent and widely dispersed in the environment and in the food chain (La Rocca and Mantovani, 2006; Schecter et al., 2010). Being highly lipophilic and chemically stable, PCBs undergo limited catabolism after absorption, accumulate in the liver and adipose tissues, and are easily transferred to the fetus through the placenta (Park et al., 2008; Grandjean et al., 2012); therefore, PCBs contamination during pregnancy could be considered as inheritable. In addition to the PCBs themselves, their metabolites can also cross the placenta and reach the developing fetus (Fängström et al., 2005; Soechitram et al., 2004; Berg et al., 2010; Grimm et al., 2015). Exposure to PCBs during intrauterine life has been associated, in humans and animals, with several health effects such as birth weight reduction, disruption of reproductive system development, immune dysfunction, and altered brain development (Schantz et al., 2003; Fowler et al., 2008; Fudvoye et al., 2014; Lignell et al., 2016; Kristensen et al., 2016).

There are 209 possible congeners of PCBs with different biological activities (ATSDR, 2004). There is evidence about the involvement of the Ah receptor (Poland and Knutson, 1982; Safe, 1994) as well as other receptors that support a role of PCBs as endocrine disruptors and interfering with calcium homeostatic mechanisms (see reviews by Kodavanti and Tilson, 1997; Tilson and Kodavanti, 1998).

The present study sought to evaluate the consequences of chronic PCBs treatment on fetal cells using an in vitro system to simulate exposure in pregnancy, thus overcoming the ethical problems connected

\footnotetext{
This work has received funding from the European Union's Horizon 2020 research and innovation programme under grant agreement 692185 (ERAofART) to G.E.P.; the European

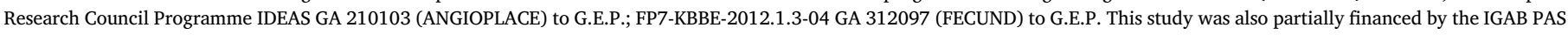
project (S.III.1.3). G.E.P. received the fellowship from EU COST action FA 1201 (Epiconcept).

* Corresponding author at: Malopolska Centre of Biotechnology, Jagiellonian University, Gronostajowa 7A str., 30-387 Krakow, Poland.

E-mail address: g.ptak@uj.edu.pl (G.E. Ptak).
} 


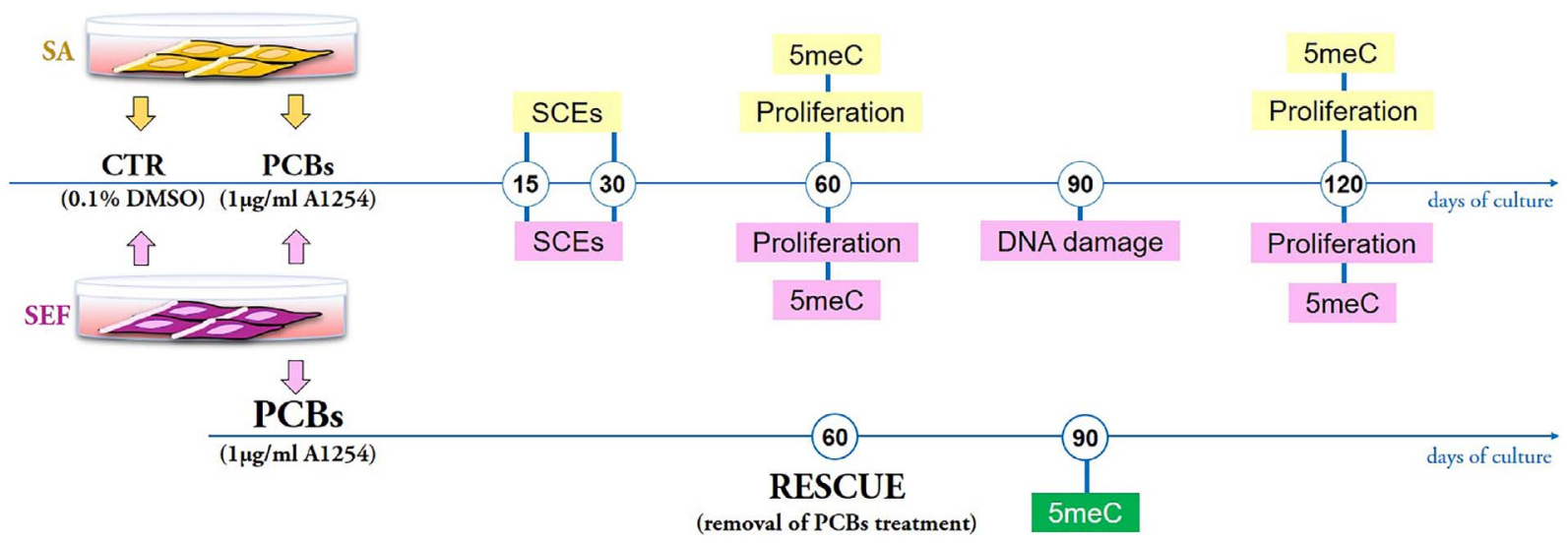

Fig. 1. Experimental design.

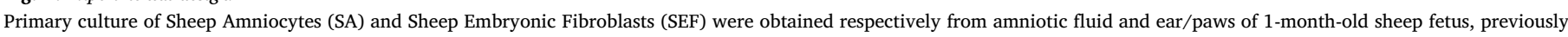

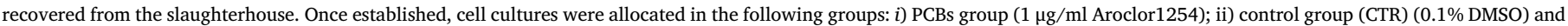

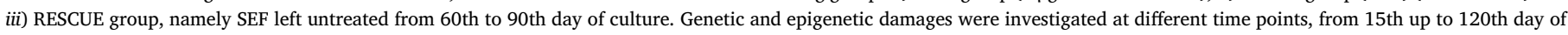

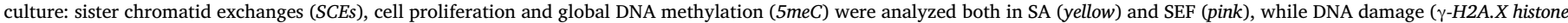

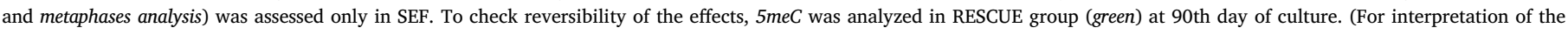
references to colour in this figure legend, the reader is referred to the web version of this article.)

to in vivo treatment. A 120 day-old cultures of sheep fetal and amniotic cells were established to mimic long-term gestational exposure and to evaluate the sensitivity to PCBs exposure of embryonic versus extraembryonic derived cytotypes. Data about genotoxic activity of PCBs mixtures are controversial, and little is known about the possibility that PCBs could interfere with epigenetic processes. Therefore, we evaluated global DNA methylation, chromosomal integrity and markers of DNA damage at different time points of PCBs exposure, as well as after interruption of the treatment, in order to evaluate the reversibility of PCBs-induced defects.

\section{Materials and methods}

All chemicals were purchased by Sigma-Aldrich, unless otherwise stated.

\subsection{Experimental design}

The experimental design is explained in Fig. 1. Starting from one month-old sheep conceptus (referred to as fetus) we have set up primary cell cultures, namely Sheep Embryonic Fibroblasts (SEF) and Sheep Amniocytes (SA), representative of fetal and extra-fetal compartments respectively. Cells were then allocated to control (CTR) and treated group (PCBs) up to 120 days of culture to mimic the entire duration of ovine pregnancy, and were analyzed at different time-points for Sister Chromatid Exchanges (SCEs), cell proliferation, and DNA global methylation. In proper fetal-derived cells, we also investigated DNA damage as $\gamma$-H2A.X histone foci and chromosomal abnormalities. Later, we tested whether the epigenetic damage, induced by PCBs, could be restores by short suspension of the treatment (RESCUE).

\subsection{Cell culture}

Cell lines used for the following experiments, have been derived from one month-old sheep fetus, previously collected from the local slaughterhouse as refuse animal material. Its age was determined based on the methods previously used (Ptak et al., 2013). Primary cultures of SEF were obtained from small pieces of fetal ears and paws by mechanical (by blades) and enzymatic (by trypsin digestion at $38.5{ }^{\circ} \mathrm{C}$ ) disaggregation, while SA were isolated by centrifugation of amniotic fluid from the same fetus, $20 \mathrm{~min}$ at $1500 \mathrm{rpm}$. Cell lines were expanded in Minimum Essential Medium (MEM) enriched with 10\% Fetal Bovine Serum (FBS), $2 \mathrm{mM}$ L-Glutamine, $26 \mathrm{mM} \mathrm{NaHCO}_{3}$ and $50 \mu \mathrm{g} / \mathrm{ml}$
Gentamicin. After three passages, cells were assigned to the following groups: $i$ ) treated group (PCBs), cultured in MEM with $1 \mu \mathrm{g} / \mathrm{ml} \mathrm{Ar-}$ oclor1254 (A1254); ii) control group (CTR), cultured in MEM enriched with $0.1 \%$ DMSO (vehicle of PCBs); iii) RESCUE group, where PCBs treatment was suspended from 60th to 90th day of culture. Medium was replaced every $48 \mathrm{~h}$ and cells were passaged whenever $80 \%$ of confluency was reached. As for our previous work (Ptak et al., 2013), the working dose of contaminants tested in this study ( $1 \mu \mathrm{g} / \mathrm{ml} \mathrm{A1254)}$ was chosen on the basis of PCBs concentration found in reproductive tissues and plasma from women of reproductive age.

\subsubsection{Cell proliferation assay}

Cell proliferation analyses was evaluated by an immunocytochemistry assay for 5-bromo-2'-deoxyuridine (BrdU), a thymidine analog incorporated during S-phase in replicating cells if previously added to culture medium. One day before the immunocytochemistry, cells were plated in multiwell slides (Millicell EZ Slide, Millipore), in number of 10,000/well. Briefly, SEF and SA at 60th and 120th day of culture were incubated with $100 \mu \mathrm{M}$ BrdU for 4-6 h, fixed in cold methanol for $20 \mathrm{~min}$ and permeabilized with $0.1 \%$ Triton X-100, $15 \mathrm{~min}$ at room temperature (RT). Next, cells were treated with $4 \mathrm{~N} \mathrm{HCl} 30 \mathrm{~min}$, RT, and incubated with primary antibody (Ab I) (mouse anti-BrdU, monoclonal antibody, B2531, Sigma) 1:100 in blocking solution (BS) (0.1\% Bovine Serum Albumin (BSA) in PBS) at $4{ }^{\circ} \mathrm{C}$, overnight. Thus, cells were incubated with secondary antibody (Ab II) (rabbit anti-mouse IgG-FITC polyclonal antibody, F9137, Sigma) 1:500 in BS for $2 \mathrm{~h} \mathrm{RT}$, and counterstained with $0.5 \mu \mathrm{g} / \mathrm{ml}$ propidium iodide (PI) for $5 \mathrm{~min}$. Between all steps, cells were washed twice in PBS, $5 \mathrm{~min}$, RT. Finally, slides were mounted with Fluoromount and observed under an epifluorescent microscope Nikon Eclipse E600, at $20 \times$ magnification. All nuclei were counted, while only the BrdU-positive nuclei have been considered as replicating cells. Cell proliferation rate was obtained by the ratio between the number of BrdU-positive cells (green) and the total number of cells (red). For statistical valence, we considered at least 200 nuclei for each group.

\subsubsection{Global DNA methylation}

Global methylation of DNA was investigated by immunofluorescence for 5-methylcytidine (5meC), on SEF and SA at 60th and 120th day of culture and on RESCUE group at 90th day of culture. One day before the immunocytochemistry, cells were plated in multiwell slides (Millicell EZ Slide, Millipore), in number of 10,000/well. Briefly, cells were fixed in $4 \%$ paraformaldehyde, $15 \mathrm{~min}$ RT, permeabilized 
with $0.1 \%$ Triton $\mathrm{X}-100,15 \mathrm{~min}$, and treated with $4 \mathrm{~N} \mathrm{HCl}$ for $30 \mathrm{~min}$ RT. Then, cells were washed with $100 \mathrm{mM}$ Tris/HCl, pH 8.5 for $15 \mathrm{~min}$ and incubated with $\mathrm{Ab} \mathrm{I}$ (mouse anti 5-methylcytidine, monoclonal antibody, 33D3, Santa Cruz Biotechnology) 1:100 in BS, one hour, RT. Next, cells were incubated with Ab II (rabbit anti-mouse IgG-FITC polyclonal antibody, F9137, Sigma) 1:500 in BS, 2 h RT, and were counterstained with $0.5 \mu \mathrm{g} / \mathrm{ml}$ PI. Between passages, cells were washed twice in PBS for 5 min. Finally, slides were mounted with Fluoromount and observed under an epifluorescent microscope Nikon Eclipse E600, at $20 \times$ magnification. DNA methylation level was quantified by analyzing the relative densitometry of nuclear fluorescence intensity, using Image Measurement and Analysis Lab software (IMAL 3.5.10.d). This software turns every fluorescent nucleus (methylation signals) into quantifiable data, subtracting the background noise. For statistical valence, we considered at least 200 nuclei for each group.

\subsection{DNA damage assessment}

\subsubsection{Sister chromatid exchange (SCE)}

Exchanges of genetic material between two sister chromatids represents recombinogenic events arising at DNA lesions. Sister chromatid exchanges can be detected following the incorporation of the thymidine analogue BrdU into DNA after two consecutive cell cycles. The SCEs are distinguishable after staining chromosomes with fluorescent dye, such as acridine orange (AO): the chromatids containing BrdU in both DNA strands, shows weaker fluorescence then those containing BrdU only in one, which appear more brightly. To visualize SCEs, we first incubated cells with $10 \mu \mathrm{g} / \mathrm{ml} \mathrm{BrdU}$ for two consecutive $\mathrm{S}$-phases of cell cycle ( $40 \mathrm{~h}$ for fibroblasts and $42 \mathrm{~h}$ for amniocytes). To obtain chromosomal metaphases, $0.5 \mu \mathrm{g} / \mathrm{ml}$ demecolcine was added to the culture medium $3 \mathrm{~h}$ prior to cell collection. Once trypsinized, cells were gently re-suspended in $10 \mathrm{ml}$ of hypotonic solution $(0.9 \% \mathrm{Na}$ citrate $/ 0.4 \% \mathrm{KCl}$ in $\mathrm{H}_{2} 0,1: 1$ ) and left for $20 \mathrm{~min}$ at $38.5^{\circ} \mathrm{C}$, after which $1 \mathrm{ml}$ of fresh fixative (methanol/glacial acetic acid 3:1) was gently added to the solution. The suspension was centrifuged $5 \mathrm{~min}$ at $1200 \mathrm{rpm}$ and the pellet resuspended in $10 \mathrm{ml}$ of fresh fixative, $15 \mathrm{~min}$ at $4{ }^{\circ} \mathrm{C}$. The solution was finally centrifuged for $5 \mathrm{~min}$ at $1200 \mathrm{rpm}$ and the pellet resuspended in $1 \mathrm{ml}$ of fresh fixative. Finally, 3/4 $50 \mu \mathrm{l}$ drops of the final suspension were spreaded on clean slides, stained with $2 \mathrm{mg} / \mathrm{ml}$ acridine orange (AO) and observed under an epifluorescent Nikon Eclipse E600 microscope at $40 \times$ magnification. We counted a minimum of 50 metaphases to estimate the percentage of SCEs per cell.

\subsubsection{Double-strand breaks (DSBs)}

DSBs were evaluated by immunocytochemistry for $\gamma$-H2A.X phosphorylated histone, an early marker of DNA damage, in SEF at 60th and 120 th day of culture. One day before the immunocytochemistry, cells were plated in multiwell slides (Millicell EZ Slide, Millipore), in number of 10,000/well. Cells were fixed and permeabilized as described above for BrdU assay, then incubated with $\mathrm{Ab}$ I (mouse anti-phospho-Histone H2A.X, Ser139, clone JBW301, Millipore) 1:100 in BS at RT for $2 \mathrm{~h}$ and with Ab II (rabbit anti-mouse IgG-FITC polyclonal antibody, F9137, Sigma) 1:200 in BS at RT for $2 \mathrm{~h}$. Between passages, cells were washed twice in PBS for $5 \mathrm{~min}$. Finally, cells were counterstained with $0.5 \mu \mathrm{g} / \mathrm{ml}$ PI, then slides were mounted with Fluoromount and observed under the epifluorescent microscope Nikon Eclipse E600. Notwithstanding an "intrinsic" phosphorylation of $\gamma$-H2A.X can occur during cell cycle progression (MacPhail et al., 2003), $\gamma$-H2A.X foci are smaller and less distinct than those induced by chemical agents (Huang et al., 2005). For this reason, only cells showing at least five distinct nuclear foci with high fluorescence intensity ( $\gamma$-H2A.X HFI foci) were considered as injured cells. Damage rate was obtained by the ration between injured cells and total cell number. For statistical valence, at least 200 nuclei for each group were considered.

\subsubsection{Cytogenetic analysis}

Chromosomes were investigated in SEF at 60th and 90th day of culture. Metaphases were obtained as described above for the SCEs assay. Briefly, $0.5 \mu \mathrm{g} / \mathrm{ml}$ demecolcine was added to the culture medium $3 \mathrm{~h}$ prior to cell collection. Once trypsinized, cells were gently re-suspended in $10 \mathrm{ml}$ of hypotonic solution $(0.9 \% \mathrm{Na}$ citrate $/ 0.4 \% \mathrm{KCl}$ in $\mathrm{H} 20,1: 1)$ and left for $20 \mathrm{~min}$ at $38.5^{\circ} \mathrm{C}$, after which $1 \mathrm{ml}$ of fresh fixative (methanol/glacial acetic acid 3:1) was gently added to the solution. The suspension was centrifuged $5 \mathrm{~min}$ at $1200 \mathrm{rpm}$ and the pellet resuspended in $10 \mathrm{ml}$ of fresh fixative and incubated $15 \mathrm{~min}$ at $4{ }^{\circ} \mathrm{C}$. Finally, the solution was centrifuged for $5 \mathrm{~min}$ at $1200 \mathrm{rpm}$ and the pellet was resuspended in $1 \mathrm{ml}$ of fresh fixative. Once spreaded on clean slides, metaphases were stained in $8 \%$ Giemsa (in $\mathrm{H}_{2} \mathrm{O}$ ) and observed under the Nikon Eclipse E600 microscope. For each metaphase, we evaluated the gain/loss of chromosomes (numerical abnormalities) and structural defects - such as chromosomal fragments and the presence of extra metacentric chromosomes - more than six - (structural anomalies). Thus, we grouped abnormal cells as follows: with only numerical chromosomal aberrations (NCA), with only structural chromosomal aberrations (SCA) and with a combination of both numerical/ structural chromosomal aberrations (N/S-CA). For statistical valence, we considered at least 50 metaphases were counted for each group.

\subsubsection{Statistical analysis}

Statistical significance was determined by GraphPad Prism 5.0 software. A Chi-square test was used for BrdU-proliferation assay, $\gamma$ H2A.X and cytogenetic analysis; a $t$-test (Mann-Whitney test) was used to evaluate global DNA methylation and to compare the frequency of SCEs among groups. We considered probability value $(p)<0.05$ as statistically significant.

\section{Results}

\subsection{PCB treatment alters proliferation}

PCBs-treated SEF displayed low proliferation along the culture (at 60th and 120th day of culture) compared to the control group $(p<0.05$; Fig. 2, SEF). On the other hand, proliferation of PCBstreated SA decreased in a time-dependent manner, since there was a significant difference in the percentage of BrdU-positive cells between amniocytes exposed to PCBs for 60 days compared to those exposed for 120 days ( $p<0.05$; Fig. 2, SA).

\subsection{PCBs induce permanent DNA hypermethylation in SEF}

Treatment with A1254 resulted in a global DNA hypermethylation, detectable after 60 and 120 days of culture in SEF compared to control $(p<0.0001)$. Conversely, DNA methylation of SAs was not affected by A1254 treatment at any of the time points analyzed (Fig. 3). Due to the dynamic nature of epigenetic/processes in relation to changing environmental conditions, we hypothesized that the global DNA hypermethylation found in SEF following treatment could be rescued after removing PCBs from the medium for one month. Surprisingly, we found that SEF treated with PCBs for 60 days and then left untreated for one further month (totally 90 days of culture) still displayed an increase in DNA methylation comparable to SEF permanently treated (Fig. 3b, RESCUE).

\section{3. $P C B$ exposure induces mutagenesis}

First, we evaluated the frequency of Sister Chromatid Exchanges per cell (SCEs/cell) in SEF and SA after 15 and 30 days of treatment, to determine the presence of recombinogenic events arising from DNA lesions. In both groups, we found higher SCEs rate in PCBs treated cells compared to control, at all analyzed time points $(p<0.001)$ as shown in Table 1 and fig. 4. 

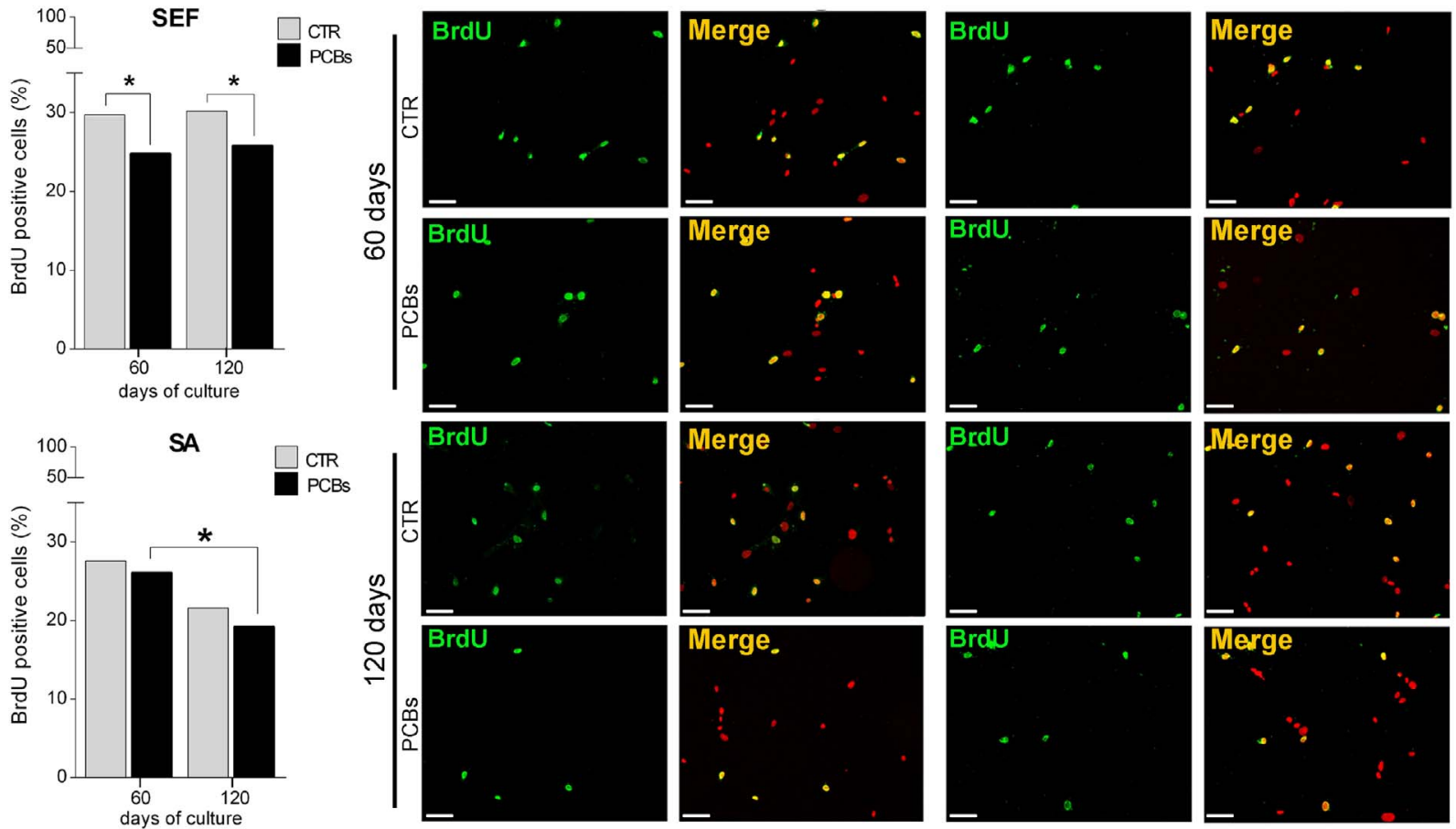

Fig. 2. PCBs alter cell proliferation.

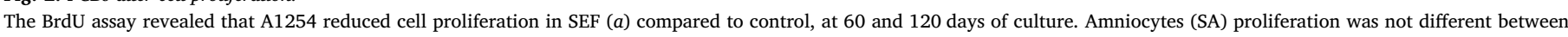

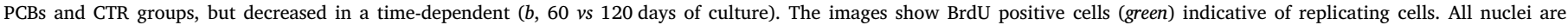

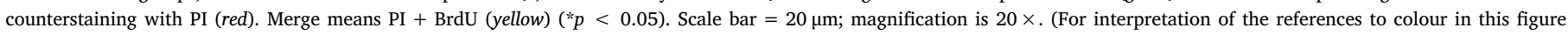
legend, the reader is referred to the web version of this article.)

To assess the genetic status of the cells belonging to proper fetal compartments, we analyzed double-strand breaks and chromosomal metaphases in SEF. Immunofluorescence for the phosphorylated form of histone $\gamma$-H2A.X - marker of double-strand breaks - revealed an increase of $\gamma$-H2A.X HFI foci in PCBs-exposed fibroblasts than control, at 60 th $(28.9 \%$ vs. $21.3 \%$, respectively) and 120 th days of culture $(44.5 \%$ vs. 34.4\%, respectively) ( $p<0.05$; Fig. 5).
The examination of metaphases revealed that untreated cells of the control group carried more numerical aberrations then the PCBs-treated group, at all analyzed time points (60 days: $64.5 \%$ vs. $8.9 \%$; 90 days: $51.4 \%$ vs. $6.9 \%$, respectively; $p<0.0001$ ) (Table 2, Fig. 6). Interestingly, PCBs-treated fibroblasts showed more serious damages, carrying both numerical and structural chromosomal aberrations, from the 60th $(82.2 \%$ vs. $19.4 \%, p<0.0001)$ to the 90 th days of culture $(87.9 \%$ vs.
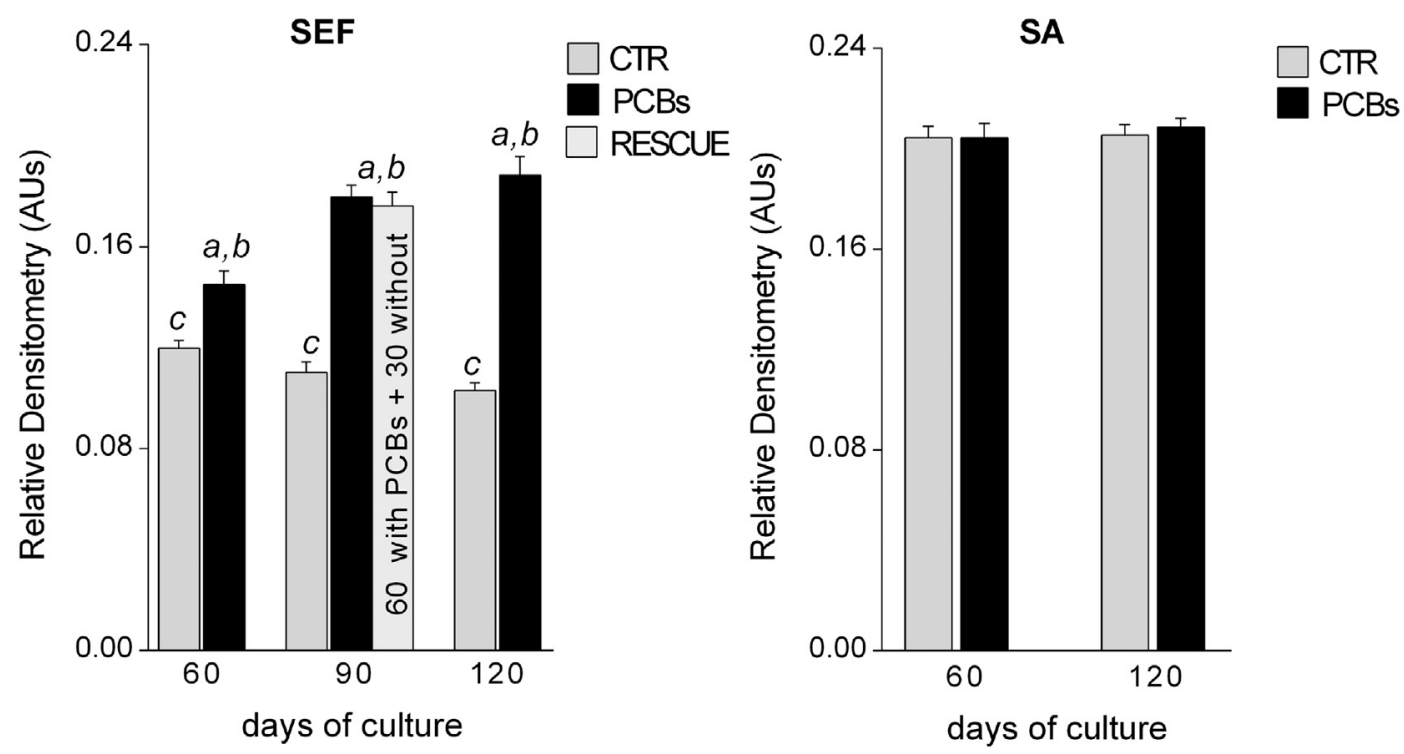

Fig. 3. PCB treatment alters global methylation in SEFs but not in SAs.

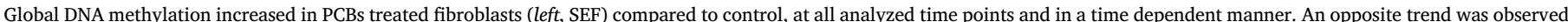

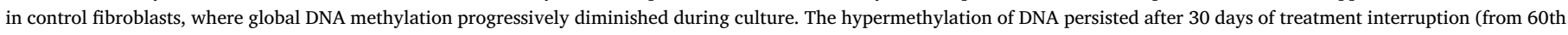

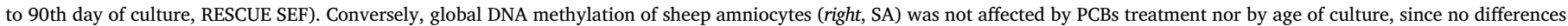

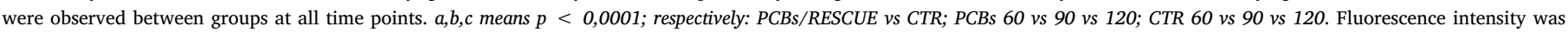
quantified by relative densitometry and is given in arbitrary units (AUs). 
Table 1

SCEs frequency in SEF and SA, at 15 and 30 days of culture.

The number of SCEs per cell was significantly higher both in fibroblasts (SEF) and in amniocytes (SA) exposed to PCBs compared to CTR, at 15 and 30 days. $a$ ) and b) mean $p<0.0001$ PCBs $v s$. CTR in SEF and SA respectively.

\begin{tabular}{llll}
\hline Groups & & Mean \pm SD \\
\hline SEF & CTR & $3.81 \pm 2.13$ & $4.50 \pm 2.13$ \\
& PCBs & $5.75 \pm 2.33^{a}$ & $7.46 \pm 3.30^{a}$ \\
SA & CTR & $4.37 \pm 2.13$ & $8.73 \pm 3.59$ \\
& PCBs & $6.97 \pm 2.9^{b}$ & $5.54 \pm 2.14^{b}$ \\
Days of culture & & 15 & 30 \\
\hline
\end{tabular}

$32.4 \%, p<0.05)$.

\section{Discussion}

Several epidemiological studies negatively correlate pregnancy exposure to polychlorinated biphenyls to impaired fetal development with growth and neurological problems in childhood. However, cellular mechanisms have not yet been clarified.

Here, we wanted to elucidate the cytotoxic effects of pregnancy exposure to PCBs, setting up a simple in vitro culture system that simulate the absorption of toxicants by anearly stage conceptus.

We found that PCBs exposure leads to recombinogenic events, double-strand breaks in the DNA and chromosomal aberrations, as well as epigenetic changes in the global DNA methylation that turn out to be permanent.

The presence of sister chromatid exchanges from the beginning of the culture is indicative of the rapid occurrence of DNA breakage (i.e. by homologous recombination) that cells attempts to repair.

Given that fibroblasts were more impaired than amniocytes in terms of cell proliferation and DNA methylation, and since amniocytes are transitory cells in the development while fibroblast are constituent part of the future organisms, we decided to investigate the DNA integrity of this latter cell type exclusively. It is known that phosphorylated form of $\gamma$-H2A.X histone represents an early marker of DNA damage, namely double-strand breaks (Bouquet et al., 2006; Löbrich et al., 2010). The high rate of $\gamma$-H2A.X foci on the DNA of PCBs-treated fibroblasts could represent the points of chromosomal rearrangement that lead to the
DNA repairing event through homologous recombination by sister chromatid exchanges (Conrad et al., 2011). A strong relationship between PCBs exposure and elevated levels of SCEs and $\gamma$-H2A.X foci has been previously reported (Venkatesha et al., 2008). It is possible that this genotoxic damage, not completely repaired, lays the groundwork for the bulk of chromosomal aberrations, leading to aneuploidy and rearrangements (Varga and Aplan, 2005; Natarajan and Palitti, 2008). The presence of severe numerical and structural chromosomal abnormalities in PCBs-exposed SEFs confirms this scenario. Furthermore, among the bizarre anomalies, it was interesting to note the formation of new supernumerary metrocentric chromosomes, clearly smaller than normal ones, probably arising from the fusion/translocation of two small acrocentric chromosomes.

Adverse environmental conditions - such as exposure to cytotoxic agents - may also result in epigenetic changes (Laurent et al., 2010) likely associated with proliferative blocks, which can arise during intrauterine life and persist from birth to death (Guerrero-Preston et al., 2011). Of note, we observed that the hypermethylation induced by PCBs in fetal cells is not reversible by interrupting the exposure to A1254. This suggests that prenatal exposure to A1254 induces the development of a permanently altered epigenetic profile that might be maintained long-term. Chromosomal instability may occur in response to epigenetic changes (Herrera et al., 2008), because though aneuploidy reduces an organism's fitness (Torres et al., 2010), an abnormal karyotype could confer advantageous properties for cell physiology, by changing gene copy numbers and subsequently, the protein balance (Sheltzer and Amon, 2011; Yona et al., 2012). Altogether, these biological alterations may contribute to the development of an abnormal phenotype. Many evidences correlate the presence of PCBs into the biological fluids of pregnant women (Bloom et al., 2007; Givens et al., 2007; Meeker et al., 2009) to negative child health outcomes (HertzPicciotto et al., 2005; Grumetto et al., 2015; Ashley-Martin et al., 2015; Hansen et al., 2016). We observed that fetal fibroblasts and amniocytes responded differently to PCB exposure probably because of their different roles into the organism and their different biological features, such as lipid content. PCBs possess high lipophilic properties (Yu and Mylander, 2011) and can accumulate mainly in cells with high lipid content (Müllerová and Kopecký, 2007; Bourez et al., 2012). In this regard, the literature reveals a lower degree of PCBs accumulation in the amniotic fluids compared to other biological compartments, such as
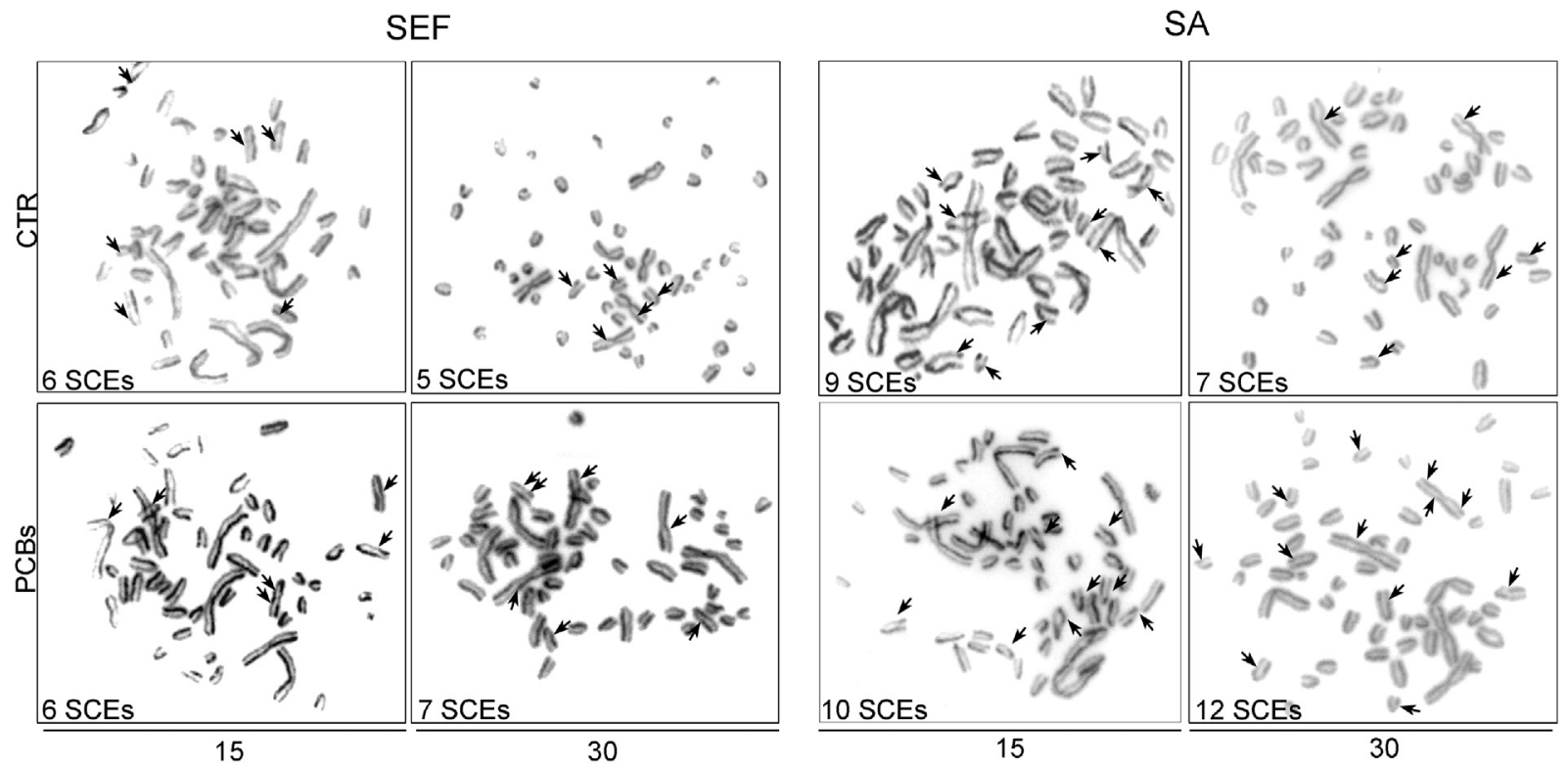

Fig. 4. Increased frequency of Sister Chromatid Exchanges (SCEs) in fibroblasts and amniocytes exposed to PCBs.

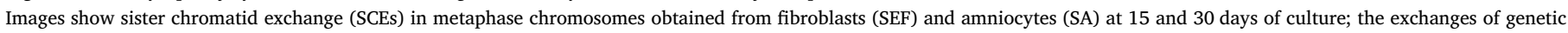
material are detectable from colour difference of two chromatids and are indicated by arrows. 

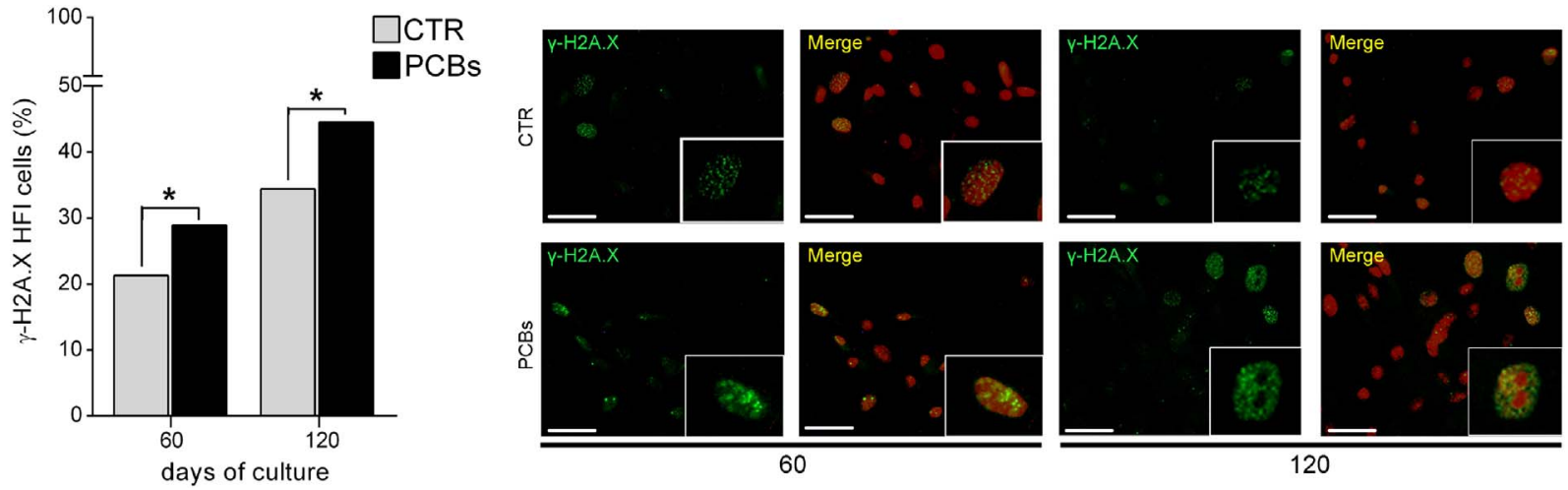

60

120

Fig. 5. PCBs enhance $\gamma-H 2 A . X$ phosphorylation, increasing DNA damage in treated fibroblasts.

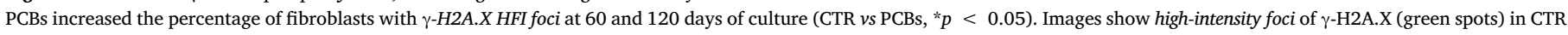

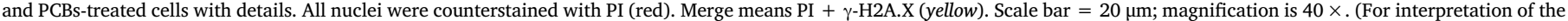
references to colour in this figure legend, the reader is referred to the web version of this article.)

Table 2

Frequency of chromosomal abnormalities in SEF.

PCBs exposure induced the development of chromosomal abnormalities in SEF ( $90 \% v s 62 \%$, PCBs $v s$ CTR). Numerical (NCA), structural (SCA) and both types (NCA-SCA) of chro-

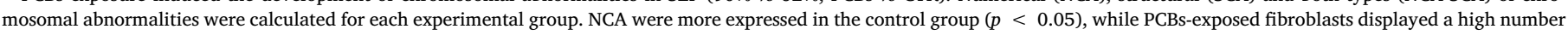

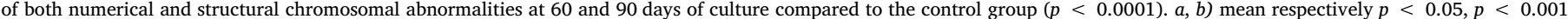
and $\mathrm{p}<0.0001$ between PCBs $v$. CTR.

\begin{tabular}{|c|c|c|c|c|c|c|c|c|}
\hline SEF & Abnormal cells (\%) & NCA (\%) & SCA (\%) & $N / S-C A(\%)$ & Abnormal cells (\%) & NCA (\%) & $S C A(\%)$ & $N / S-C A(\%)$ \\
\hline CTR & $31 / 50(62 \%)$ & $20 / 31(64.5 \%)$ & $5 / 31(16.1 \%)$ & 6/31 (19.4\%) & $37 / 65(56.9 \%)$ & $19 / 37$ (51.4\%) & $6 / 37(16.2 \%)$ & $12 / 37(32.4 \%)$ \\
\hline PCBs & $45 / 50(90 \%)^{b}$ & $\begin{array}{l}4 / 45 \\
(8.9 \%)^{a}\end{array}$ & $\begin{array}{l}4 / 45 \\
(8.9 \%)\end{array}$ & $\begin{array}{l}37 / 45 \\
(82.2 \%)^{c}\end{array}$ & $58 / 60(96.6 \%)^{a}$ & $\begin{array}{l}4 / 58 \\
(6.9 \%)^{a}\end{array}$ & $\begin{array}{l}3 / 58 \\
(5.2 \%)\end{array}$ & $\begin{array}{l}51 / 58 \\
(87.9 \%)^{c}\end{array}$ \\
\hline Days of culture & 60 & & & & 90 & & & \\
\hline
\end{tabular}

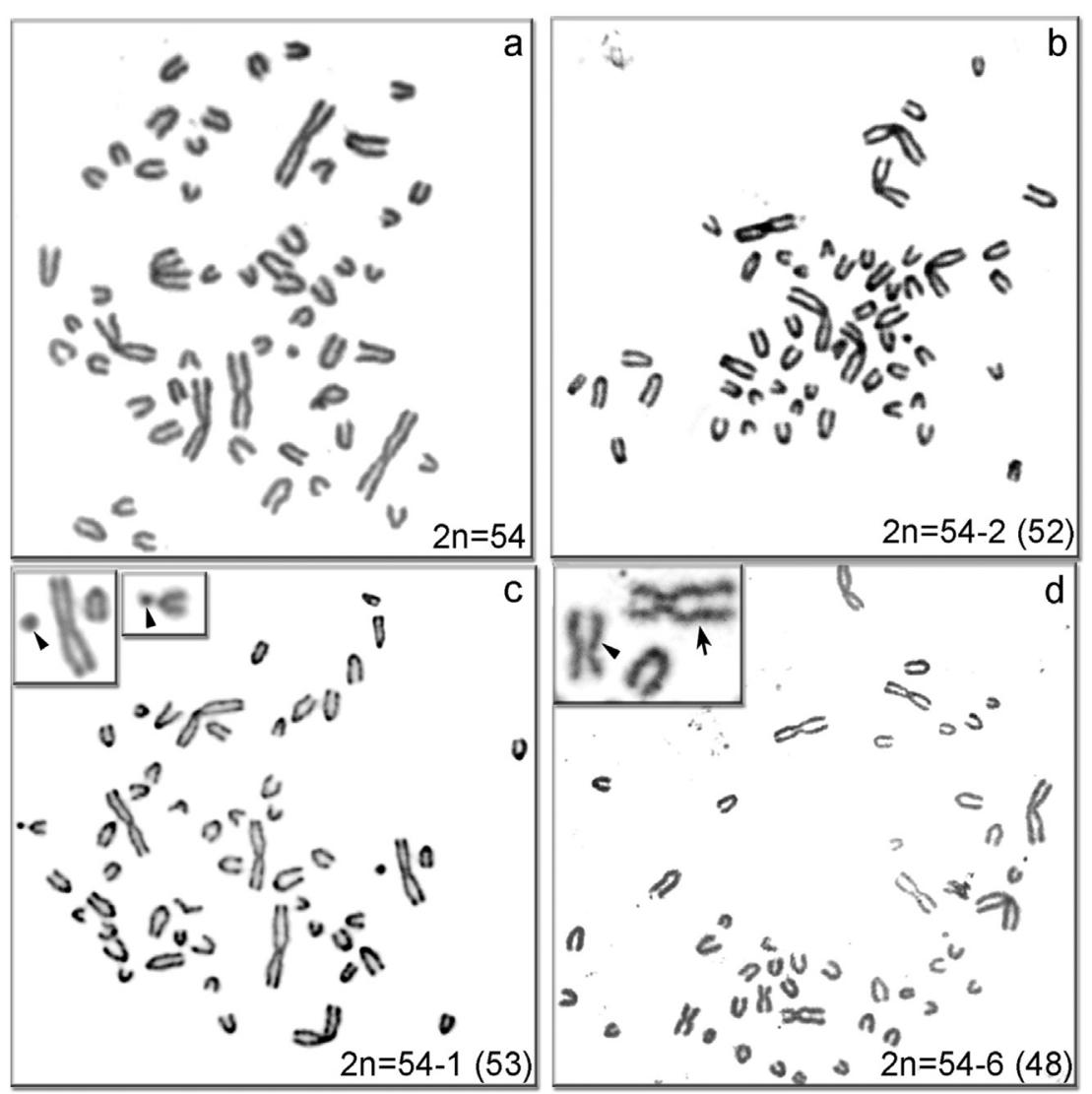

Fig. 6. Kinds of chromosomal abnormalities in PCB-treated fibroblasts.

Images show some representative metaphase chromosomes found in SEF: a) normal karyotype; b) aneuploidy, $2 \mathrm{n}-2=52$; c) structural abnormalities (2n-1 = 53) (magnification shows little fragment of chromosome, not distinguishable from the $\mathrm{Y}$ chromosome, both indicated by arrowhead); d) numerical and structural abnormalities (magnification shows small micro-metrocentric-arrowhead-and submetrocentric-arrow- chromosomes, not detectable into a normal ovine karyotype). 
the placenta (Foster et al., 2000; Jarrell et al., 2005). It is easier to discover some PCB metabolites than congeners (Gallenberg et al., 1990; Grimm et al., 2015). This observation invites us to reflect about the analysis of extra-embryonic cells (i.e. amniocytes) in women exposed to PCBs during gestation, because could underestimate the level of PCBs, providing values not correspondent to the real rate of contamination within the proper fetal compartments. These very serious and irreversible genetic and epigenetic abnormalities may influence intrauterine life, compromising both prenatal and post-natal growth up to adulthood.

This in vitro system - which is similar to gestation for cells and duration of culture - fills important gaps in the knowledge of how pregnancy exposure to PCBs causes genotoxic damage, and sets the stage for targeted in vivo studies.

\section{Conflict of interest}

The authors have no competing interests to declare.

\section{Study funding/competing interests}

This work was supported by the European Research Council (FP7/ 2007-2013)/Programme IDEAS GA no. 210103 to G.E.P.; European Research Council - programme FP7-KBBE-2012.1.3-04, GA no. 312097 Acronym: FECUND to G.E.P. The authors are participating in the COST action FA 1201 "Epiconcept" Epigenetic and Periconception Environment. The authors have no competing interests to declare.

\section{Transparency document}

The Transparency document associated with this article can be found, in online version.

\section{References}

Agency for Toxic Substances and Disease Registry (ATSDR), 2004. Interaction Profile for Persistent Chemicals found in Fish.

Ashley-Martin, J., Levy, A.R., Arbuckle, T.E., Platt, R.W., Marshall, J.S., Dodds, L., 2015. Maternal exposure to metals and persistent pollutants and cord blood immune system biomarkers. Environ. Health 14, 52.

Berg, V., Lyche, J.L., Gutleb, A.C., Lie, E., Skaare, J.U., Aleksandersen, M., Ropstad, E., 2010. Distribution of PCB 118 and PCB 153 and hydroxylated PCB metabolites (OHCBs) in maternal, fetal and lamb tissues of sheep exposed during gestation and lactation. Chemosphere 80, 1144-1150.

Bloom, M.S., Buck Louis, G.M., Schisterman, E.F., Liu, A., Kostyniak, P.J., 2007. Maternal serum polychlorinated biphenyl concentrations across critical windows of human development. Environ. Health Perspect. 115, 1320-1324.

Bouquet, F., Muller, C., Salles, B., 2006. The Loss of gH2AX Signal is a Marker of DNA Double Strand Breaks Repair Only at Low Levels of DNA Damage. Cell Cycle 5, 1116-1122.

Bourez, S., Le Lay, S., Van den Daelen, C., Louis, C., Larondelle, Y., Thomé, J.P., Schneider, J.Y., Dugail, I., Debier, C., 2012. Accumulation of polychlorinated biphenyls in adipocytes: selective targeting to lipid droplets and role of caveolin-1. PLoS One 7 (2), e31834

Conrad, S., Künzel, J., Löbrich, M., 2011. Sister chromatid exchanges occur in G2-irradiated cells. Cell Cycle 10, 222-228.

Fängström, B., Hovander, L., Bignert, A., Athanassiadis, I., Linderholm, L., Grandjean, P., Weihe, P., Bergman, A., 2005. Concentrations of polybrominated diphenyl ethers, polychlonnated biphenyls, and polychlorobiphenylols in serum from pregnant Faroese women and their children 7 years later. Environ. Sci. Technol. 39, 9457-9463.

Foster, W., Chan, S., Platt, L., Hughes, C., 2000. Detection of endocrine disrupting chemicals in samples of second trimester human amniotic fluid. J. Clin. Endocrinol. Metab. 85, 2954-2957.

Fowler, P.A., Dora, N.J., McFerran, H., Amezaga, M.R., Miller, D.W., Lea, R.G., Cash, P., AS, McNeilly, Evans, N.P., Cotinot, C., Sharpe, R.M., Rhind, S.M., 2008. In utero exposure to low doses of environmental pollutants disrupts fetal ovarian development in sheep. Mol. Hum. Reprod. 14, 269-280.

Fudvoye, J., Bourguignon, J.P., Parent, A.S., 2014. Endocrine-disrupting chemicals and human growth and maturation: a focus on early critical windows of exposure. Vitam. Horm. 94, 1-25.

Gallenberg, L.A., Ring, B.J., Vodicnik, M.J., 1990. The influence of time of maternal exposure to $2,4,5,2^{\prime}, 4^{\prime}, 5^{\prime}$-hexachlorobiphenyl on its accumulation in their nursing offspring. Toxicol. Appl. Pharmacol. 104, 1-8.

Givens, M.L., Smalla, C.M., Terrella, M.L., Cameronc, L.L., Blanckd, H.M., Tolberta, P.E.,
Rubine, C., Hendersonf, A.K., Marcusa, M., 2007. Maternal exposure to polybrominated and polychlorinated biphenyls: infant birth weight and gestational age. Chemosphere 69, 1295-1304.

Grandjean, P., Weihe, P., Nielsen, F., Heinzow, B., Debes, F., Budtz-JØrgensen, E., 2012 Neurobehavioral deficits at age 7 years associated with prenatal exposure to toxicants from maternal seafood diet. Neurotoxicol. Teratol. 34, 466-472.

Grimm, F.A., Hu, D., Kania-Korwel, I., Lehmler, H.J., Ludewig, G., Hornbuckle, K.C., Duffel, M.W., Bergman, A., Robertson, L.W., 2015. Metabolism and metabolites of polychlorinated biphenyls (PCBs). Crit. Rev. Toxicol. 45, 245-272.

Grumetto, L., Ortosecco, G., Russo, G., Guida, M., Ferranti, P., Nasi, A., Barbato, F., 2015. Dioxin-like PCB levels in maternal and umbilical cord sera of people living near dump sites in southern Italy: a pilot study of biomonitoring. Environ. Monit. Assess. $187,88$.

Guerrero-Preston, R., Herbstman, J., Goldman, L.R., 2011. Epigenomic biomonitors: global DNA hypomethylation as a biodosimeter of life-long environmental exposures. Epigenomics 3, 1-5.

Hansen, S., Strøm, M., Olsen, S.F., Dahl, R., Hoffmann, H.J., Granström, C., Rytter, D., Bech, B.H., Linneberg, A., Maslova, E., Kiviranta, H., Rantakokko, P., Halldorsson, T.I., 2016. Prenatal exposure to persistent organic pollutants and offspring allergic sensitization and lung function at 20 years of age. Clin. Exp. Allergy 46, 329-336.

Herrera, L.A., Prada, D., Andonegui, M.A., Dueñas-González, A., 2008. The epigenetic origin of aneuploidy. Curr. Genomics 9, 43-50.

Hertz-Picciotto, I., Charles, M.J., James, R.A., Keller, J.A., Willman, E., Teplin, S., 2005. In utero polychlorinated biphenyl exposures in relation to fetal and early childhood growth. Epidemiology 16 (5), 56-64.

Huang, X., Halicka, H.D., Traganos, F., Tanaka, T., Kurose, A., Darzynkiewicz, Z., 2005. Cytometric assessment of DNA damage in relation to cell cycle phase and apoptosis. Cell Prolif. 38, 223-243.

Jarrell, J., Chan, S., Hauser, R., Hu, H., 2005. Longitudinal assessment of PCBs and chlorinated pesticides in pregnant women from Western Canada. Environ. Health 1, 4-10.

Kodavanti, P.R., Tilson, H.A., 1997. Structure-activity relationships of potentially neurotoxic PCB congeners in the rat. Neurotoxicology 18, 425-441.

Kristensen, S.L., Ramlau-Hansen, C.H., Ernst, E., Olsen, S.F., Bonde, J.P., Vested, A. Halldorsson, T.I., Rantakokko, P., Kiviranta, H., Toft, G., 2016. Prenatal exposure to persistent organochlorine pollutants and female reproductive function in young adulthood. Environ. Int. 92-93, 366-372.

La Rocca, C., Mantovani, A., 2006. From environment to food: the case of PCB. Ann. Ist. Super. Sanità 42, 410-416.

Laurent, L., Wong, E., Li, G., Huynh, T., Tsirigos, A., Ong, Chin Thing, Low, Hwee Meng, Sung, Ken Wing Kin, Rigoutsos, I., Loring, J., Wei, Chia-Lin, 2010. Dynamic changes in the human methylome during differentiation. Genome Res. 20, 320-331.

Lignell, S., Aune, M., Darnerud, P.O., Stridsberg, M., Hanberg, A., Larsson, S.C., Glynn, A., 2016. Maternal body burdens of PCDD/Fs and PBDEs are associated with maternal serum levels of thyroid hormones in early pregnancy: a cross-sectional study. Environ. Health 15, 55.

Löbrich, M., Shibata, A., Beucher, A., Fisher, A., Ensminger, M., Goodarzi, A.A., Barton, O., Jeggo, P.A., 2010. $\gamma \mathrm{H} 2 \mathrm{AX}$ foci analysis for monitoring DNA double-strand break repair. Strengths, limitations and optimization. Cell Cycle 9, 662-669.

MacPhail, S.H., Banáth, J.P., Yu, Y., Chu, E., Olive, P.L., 2003. Cell cycle-dependent expression of phosphorylated histone H2AX: reduced expression in unirradiated but not X-irradiated G1-phase cells. Radiat. Res. 159, 759-767.

Meeker, J.D., Missmer, S.A., Altshul, L., Vitonis, A.F., Ryan, L., Cramer, D.W., Hauser, R. 2009. Serum and follicular fluid organochlorine concentrations among women undergoing assisted reproduction technologies. Environ. Health 8, 32.

Müllerová, D., Kopecký, J., 2007. White adipose tissue: storage and effector site for environmental pollutants. Physiol. Res. 56, 375-381.

Natarajan, A.T., Palitti, F., 2008. DNA repair and chromosomal alterations. Mutat. Res. $17,3-7$.

Park, J.S., Bergman, A., Linderholm, L., Athanasiadou, M., Kocan, A., Petrik, J., Drobna, B., Trnovec, T., Charles, M.J., Hertz-Picciotto, I., 2008. Placental transfer of polychlorinated biphenyls, their hydroxylated metabolites and pentachlorophenol in pregnant women from Eastern Slovakia. Chemosphere 70, 1676-1684.

Poland, A., Knutson, J.C., 1982. 2,3,7,8-tetrachlorodibenzo-p-dioxin and related halogenated aromatic hydrocarbons: examination of the mechanism of toxicity. Annu. Rev. Pharmacol. Toxicol. 22, 517-554.

Ptak, G.E., D'Agostino, A., Toschi, P., Fidanza, A., Zacchini, F., Czernik, M., Monaco, F., Loi, P., 2013. Post-implantation mortality of in vitro produced embryos is associated with DNA methyltransferase 1 dysfunction in sheep placenta. Hum. Reprod. 28 298-305.

Safe, S., 1992. Toxicology, structure-function relationship, and human and environmental health impacts of polychlorinated biphenyls: progress and problems. Environ. Health Perspect. 100, 259-268.

Safe, S.H., 1994. Polychlorinated biphenyls (PCBs): environmental impact, biochemical and toxic responses, and implications for risk assessment. Crit. Rev. Toxicol. 24, 87-149.

Schantz, S.L., Widholm, J.J., Rice, D.C., 2003. Effects of PCB exposure on neuropsychological function in children. Environ. Health Perspect. 111, 357-576.

Schecter, A., Colacino, J., Haffner, D., Patel, K., Opel, M., Papke, O., Birnbaum, L., 2010. Perfluorinated compounds, polychlorinated biphenyls, and organochlorine pesticide contamination in composite food samples from Dallas, Texas, USA. Environ. Health Perspect. 118, 796-802.

Sheltzer, J.M., Amon, A., 2011. The aneuploidy paradox: costs and benefits of an incorrect karyotype. Trends Genet. 27, 446-453.

Soechitram, S.D., Athanasiadou, M., Hovander, L., Bergman, A., Sauer, P.J., 2004. Fetal exposure to PCBs and their hydroxylated metabolites in a Dutch cohort. Environ. 
Health Perspect. 112, 1208-1212.

Tilson, H.A., Kodavanti, P.R., 1998. The neurotoxicity of polychlorinated biphenyls. Neurotoxicology 19, 517-525.

Torres, E.M., Williams, B.R., Amon, A., 2010. Aneuploidy: cells losing their balance. Genetics 179, 737-746.

Varga, T., Aplan, P.D., 2005. Chromosomal aberrations induced by double strand DNA breaks. DNA Repair 4, 1038-1046.

Venkatesha, V.A., Venkataraman, S., Sarsour, E.H., Kalen, A.L., Buettner, G.R., Robertson,
L.W., Lehmler, H.J., Goswami, P.C., 2008. Catalase ameliorates polychlorinated biphenyl-induced cytotoxicity in non-malignant human breast epithelial cells. Free Radic. Biol. Med. 45, 1094-1102.

Yona, A.H., Manor, Y.S., Herbst, R.H., Romano, G.H., Mitchell, A., et al., 2012. Proc. Natl. Acad. Sci. U. S. A. 109, 21010-21015.

Yu, G.W., Laseter, J., Mylander, C., 2011. Persistent organic pollutants in serum and several different fat compartments in humans. J. Environ. Public Health 2001, 41780. 